\title{
Production of recombinant enzymes of wide use for research
}

\author{
María J. Manzur \\ Departamento de Bioquímica y Ciencias Biológicas \\ Facultad de Química, Bioquímica y Farmacia \\ Universidad Nacional de San Luis \\ Ejército de los Andes 950 \\ San Luis, Argentina \\ Tel/Fax: 542652422644 \\ E-mail:mjmanzu@unsl.edu.ar

\section{Rosana V. Muñoz} \\ Departamento de Bioquímica y Ciencias Biológicas \\ Facultad de Química, Bioquímica y Farmacia \\ Universidad Nacional de San Luis \\ Ejército de los Andes 950 \\ San Luis, Argentina \\ Tel/Fax: 542652422644 \\ E-mail: munoz@bio.puc.cl
}

\section{Adrián A. Lucero}

Departamento de Bioquímica y Ciencias Biológicas

Facultad de Química, Bioquímica y Farmacia

Universidad Nacional de San Luis

Ejército de los Andes 950

San Luis, Argentina

Tel/Fax: 542652422644

E-mail: adrian_lucerhoff@yahoo.com

\section{Maximiliano Juri Ayub}

Departamento de Bioquímica y Ciencias Biológicas

Facultad de Química, Bioquímica y Farmacia

Universidad Nacional de San Luis

Ejército de los Andes 950

San Luis, Argentina

Tel/Fax: 542652422644

E-mail: juriayub@dna.uba.ar

\section{Sergio E. Alvarez}

Departamento de Bioquímica y Ciencias Biológicas

Facultad de Química, Bioquímica y Farmacia

Universidad Nacional de San Luis

Ejército de los Andes 950

San Luis, Argentina

Tel/Fax: 542652422644

E-mail: sealvar@unsl.edu.ar

\section{Gladys M. Ciuffo*}

Departamento de Bioquímica y Ciencias Biológicas Facultad de Química, Bioquímica y Farmacia

Universidad Nacional de San Luis

Ejército de los Andes 950

San Luis, Argentina

Tel/Fax: 542652422644

E-mail: gciuffo@unsl.edu.ar

Financial support: Grant from the Universidad Nacional de San Luis, Argentina.

Keywords: bioactivity, protein expression, purification, recombinant enzymes.

\footnotetext{
* Corresponding author
} 
Abbreviations: Ang II: Angiotensin II

$\mathrm{AT}_{2}$ : Angiotensin II type 2 receptor

GAPDH: Glyseraldehyde-3-phosphate dehydrogenase

MMLV: Moloney murine Leukemia Virus

PND: post-natal day

SN: supernatant

For biotechnological purposes, protein expression refers to the directed synthesis of large amounts of desired proteins. The aim of the present work was to produce reverse transcriptase Moloney murine Leukaemia Virus retro-transcriptase and Taq DNA polymerase, as bioactive products. In the present paper, we report the preparation of recombinant enzymes, expressed in $E$. coli strains. The enzymes produced exhibited quite good activity, compared with commercial enzymes, allowing us to replace the last ones for several lab applications. We are reporting changes and modifications to standard protocols described. The standard protocols were modified, i.e. for the purification step of Taq, a temperature dependent procedure was designed. The enzymes produced were used in different applications, such as PCR, RT-PCR, PCR Multiplex and RAPDs molecular markers.

Protein expression refers to the directed synthesis of large amounts of desired proteins. Many of the revolutionary changes that have occurred in the biological sciences over the past $15-20$ years can be directly attributed to the ability to manipulate DNA in defined ways (Thatcher and Hitchcock, 1994). The major tools for genetic engineering are the enzymes that catalyze specific reactions on DNA/RNA molecules. Taq DNA polymerase and Moloney murine Leukaemia Virus (MMLV) retrotranscriptase are widely used enzymes for research in laboratories applying molecular biology methods. Recombinant enzymes are available in the market but at high prices. To reduce the cost of lab experiences, we made the effort to produce our own recombinant enzymes.

The success of modern biotechnology results from the ability to express foreign or heterologous genes in a host organism. However, transcription and translation of a recombinant gene do not always lead to the accumulation of a folded fully active protein (Price and Stevens, 1999). It is well-known that artificially induced abnormal proteins, as well as foreign proteins accumulate in an insoluble state, known as inclusion bodies, which contain almost pure protein held together by non covalent force which could only be solubilized with strong denaturing agents (Thatcher and Hitchcock, 1994). The biotechnology challenge is to exploit the inclusion body phenomenon, and to convert the
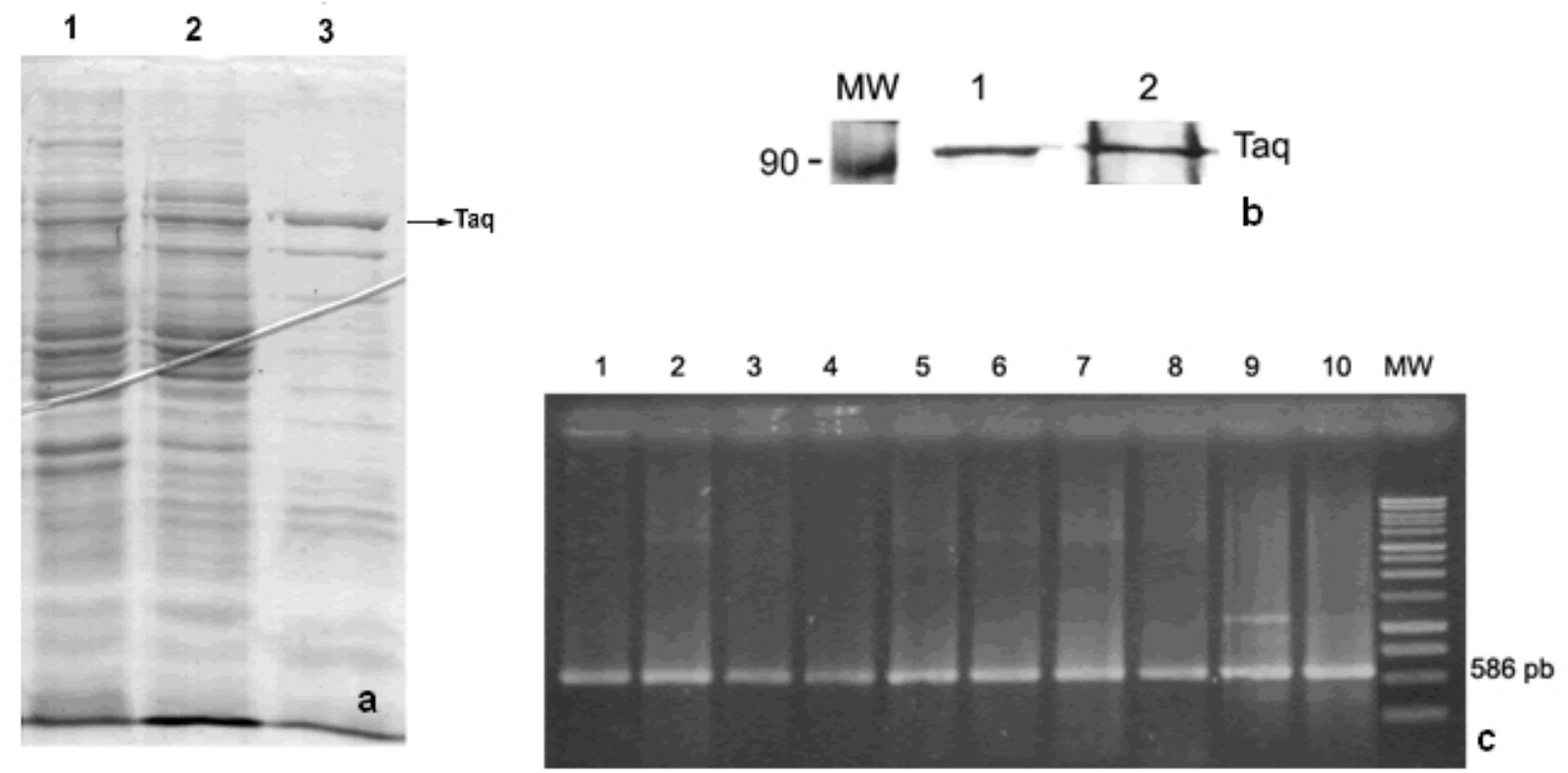

Figure 1. Purification of Taq polimerase and activity assay.

(a) SDS-PAGE (12.5\%) of aliquots of the preparation at different purification steps. Lane 1: solubilized proteins after $11 \mathrm{hrs}$ of IPTG (1 mM) induction. Lane 2: SN obtained after the sonication step. Lane 3: proteins remaining after purification by heat.

(b) SDS-PAGE (12.5\%, silver staining) of the commercial (lane 1) and produced (lane 2) Taq polimerase.

(c) Amplification products of the $\mathrm{AT}_{2}$ Ang II receptor, obtained with the produced Taq polimerase (lanes 1-8) and commercial one (lanes 9-

10). Lanes 1-8: volumes of Taq employed ( $\mu \mathrm{l})$ : 1 (0.3), 2 (0.4), 3 (0.5), 4 (0.6), 5 (0.7), $6(0.8), 7$ (0.9), 8 (1). Lanes 9-10: 0.3 and 0.4 $\mu \mathrm{l}$, commercial Taq. MW: molecular weight ladder, $1 \mathrm{~kb}$. 
protein encapsulated into a useful bioactive product. It has been suggested that protein deposited in these inclusions are aggregates of misfolded protein (Bowden et al. 1991; Chaffotte et al. 1992; Thatcher and Hitchcock, 1994).

The aim of the present work was to produce reverse transcriptase MMLV and Taq DNA polimerase, as bioactive products. Thus, we set up a protocol for the expression of recombinant proteins in E. coli to obtain enzymes of high purity and specific activity. We are reporting changes and modifications to standard protocols described in the literature (Engelke et al. 1990; Pluthero, 1993; Ottino, 1998; Taube,1998).

\section{MATERIALS AND METHODS}

Standard protocols were used for the production of recombinant proteins including the following steps.

\section{Transformation of competent cells}

Competent cells were generated starting from the strain $E$. coli DH5 $\alpha$ and BL21(DE3) by using the $\mathrm{CaCl}_{2}$ standard protocol (Ausubel et al. 1999). Competent cells were transformed using the vector pTTQ18 containing the sequence of Taq with a selection marker for Ampiciline (Amp) and a vector containing the MMLV sequence and selection markers for Chloranfenicol and Kanamycine (both vectors were generously provided by Ing. Masuelli, Fac. Cs. Agrarias, Mza). Transformation was carried out by thermic shock: competent bacteria were incubated with the vector $10 \mathrm{~min}$ on ice, followed by incubation at $42^{\circ} \mathrm{C}$ for 2 min and a final step at $4^{\circ} \mathrm{C}$. The transformants were resuspended in $500 \mu \mathrm{l}$ of culture media containing antibiotics, spread on a plate and incubated at $37^{\circ} \mathrm{C}$.

\section{Expression induction with IPTG}

Induction was performed for different times with Isopropil $\beta$-thiogalactoside (IPTG, $1 \mathrm{mM}$ ) in the appropriate culture media. Expression was controlled by analyzing aliquots of material obtained at the different steps by SDS-PAGE $(12 \%)$. Once the best conditions for time, IPTG concentration and other variables were set up, a larger scale culture was performed, which was used for protein purification (Lawyer et al. 1989; Bollag et al. 1996; Ausubel et al. 1999).

\section{Purification}

Purification of Taq polymerase. To purify Taq polymerase we took advantage of the resistance of the enzyme to high temperatures and designed a purification based on heating. The pellet of bacteria was resuspended in PBS with $4 \mathrm{mg} / \mathrm{ml}$ of lysozyme and the mixture was exposed to several cycles of frozen/melting steps to favour cellular breakage. After sonication (3 pulses), cellular lysates were centrifuged and the supernatant (SN) recovered. The $\mathrm{SN}$ was heated at $72^{\circ} \mathrm{C}$ for $1 \mathrm{hr}$ and then centrifuged at $15000 \mathrm{xg}$, Taq polymerase remains in the SN. Purified proteins were dialyzed against storage buffer (50 mM Tris- $\mathrm{HCl} \mathrm{pH}=8,100 \mathrm{mM} \mathrm{NaCl}, 0.1 \mathrm{mM}$ EDTA y $2 \mathrm{mM} \beta$-mercaptoethanol), in two steps, lasting three days. Sterile glycerol was added to the dialyzed material to a final concentration of $50 \%$ to cryoprotect the enzyme and stored at $-20^{\circ} \mathrm{C}$. Reaction buffer $(10 \mathrm{x})$ free of $\mathrm{Mg}$ was prepared $(10 \mathrm{mM}$ Tris- $\mathrm{HCl}(\mathrm{pH} 9.0), 50 \mathrm{mM} \mathrm{KCl}$ and $0.1 \%$, Triton $\mathrm{X}-100)$.
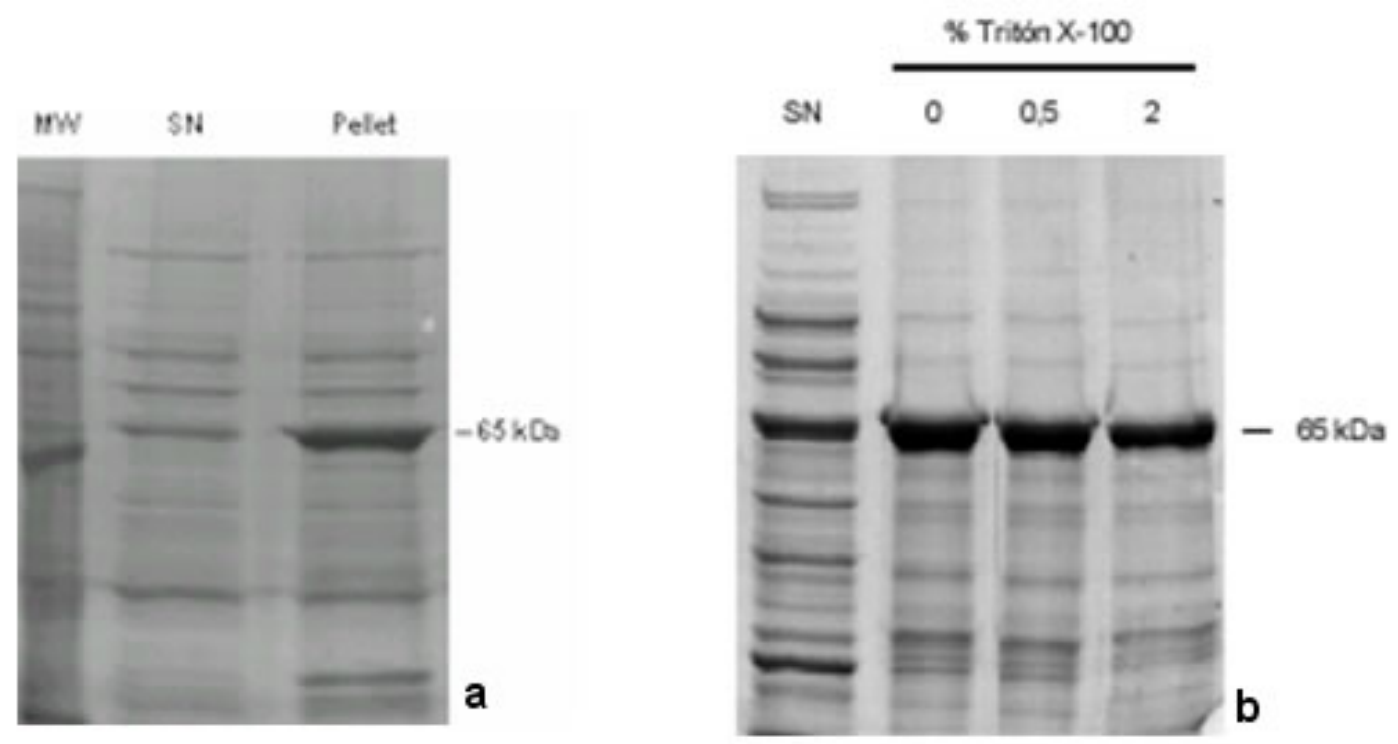

Figure 2. Purification of the retrotranscriptase.

(a) Induced over expression of MMLV in SN and inclusion bodies SDS-PAGE gels (7.5\%), stained with CBB.

(b) Purification from inclusion bodies and dialysis with different triton X-100 concentrations. SDS-PAGE gels (7.5\%), stained with CBB. 
MMLV purification. Bacterial slurry was centrifuged at $4000 \mathrm{rpm}$ for $10 \mathrm{~min}$ and the pellet was resuspended in 30 $\mathrm{ml}$ wash buffer $\left(50 \mathrm{mM} \mathrm{Na}_{2} \mathrm{HPO}_{4} \mathrm{pH} 8,0.3 \mathrm{M} \mathrm{NaCl}, 5 \mathrm{mM}\right.$ 2-mercaptoethanol). Cellular lysis was achieved by treatment with lysozyme $1 \mathrm{mg} / \mathrm{ml}$ and sonication as described above. Aliquots were centrifuged at $5000 \mathrm{xg}$ for $15 \mathrm{~min}$. SDS-PAGE analysis indicates that the protein of interest was present in the soluble fraction as well as in the inclusion body fraction. Inclusion bodies were resuspended in wash buffer containing $0 \%, 0,5 \%$ and $2 \%$ of Triton X100. Three washes with Triton X-100, followed by 3 washes without detergent were performed. The pellet was resuspended in $1 \mathrm{ml}$ of solubilization buffer $(50 \mathrm{mM}$ Tris $\mathrm{pH} 8,8 \mathrm{M}$ Urea, $0.3 \mathrm{M} \mathrm{NaCl}, 5 \mathrm{mM} 2$ - $\beta$-mercaptoethanol). Following centrifugation $(12000 \mathrm{xg}, 1 \mathrm{hr})$ the $\mathrm{SN}$ was diluted in solubilization buffer and protein was renatured by dialysis at $4^{\circ} \mathrm{C}$ against $50-100 \mathrm{~V}$ of renaturation buffer. The dialyzed material was centrifuged at $13000 \mathrm{xg}(1 \mathrm{hr})$ and the SN resuspended with the same volume of glycerol and stored at $-20^{\circ} \mathrm{C}$.

\section{Activity assays}

The enzymatic activity was verified by means of different RT or PCR assays, using variable conditions: enzyme volume, $\mathrm{MgCl}_{2}$ concentrations, etc.

PCR. Aliquots of DNA from adult rat kidney were used to amplify the $\mathrm{AT}_{2}$ receptor subtype of Ang II, following standard protocols to amplify the fragment of interest (Dieffenbach and Dveksler, 1995; Nickenig et al. 1997).

RT-PCR assay. RNAs obtained from cerebellum of different ages (TRIzol, GIBCO) were used to produce cDNA by retrotranscription in a first step (RT) and then amplification was conducted for $\mathrm{AT}_{2}$ and GAPDH fragments by PCR assays as described (Ciuffo et al. 1996).

RFLP. Amplification products were digested with the indicated enzymes.

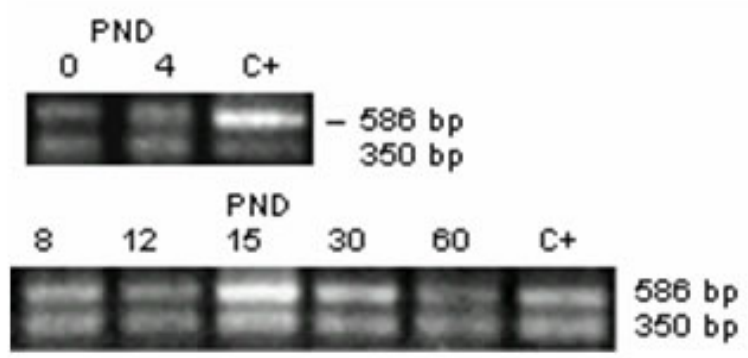

Figure 3. RT-PCR co-amplification by PCR Multiplex. Co-amplification of $\mathrm{AT}_{2}$ receptor (586 bp) and GAPDH (350 bp) in cerebellum at different developmental stages. Upper Panel: PNDO (PND: post-natal day) and PND4. Lower Panel: PND8 to PND60. Etidium bromide staining. Experiment representative of four independent experiences. C+: positive control.

\section{RESULTS AND DISCUSSION}

Following the procedures described under Methods, the recombinant enzymes were expressed and purified from $E$. coli DH5 $\alpha$ and BL21 cultures (Figure 1 and Figure 2). Figure 1 shows the purification steps followed to produce Taq polymerase enzyme (SDS-PAGE, Coomasie staining). Figure $1 \mathrm{~b}$ shows the silver staining of the commercial and the Taq polymerase obtained in this work. In order to test the enzymatic activity of the enzyme we performed amplification of the $\mathrm{AT}_{2}$ receptor with a commercial enzyme and compare with the amplification of $\mathrm{AT}_{2}$ receptor with increasing amounts $(0.3$ to $1 \mu \mathrm{l})$ of the produced enzyme, following a previously described PCR protocol (Ciuffo et al. 1996). Figure 1c shows amplification products for the $\mathrm{AT}_{2}$ receptor (586 bp) with all the enzyme volumes used, having a more specific amplification product with the prepared enzyme. A well-defined band of the expected size was obtained with our enzyme. The signal obtained with $0.4 \mu \mathrm{l}$ of the enzyme was comparable to the one obtained with $0.3 \mu \mathrm{l}$ of the commercial enzyme. From these experiences, the estimated specific activity was 2-5 $\mathrm{U} / \mu 1$. In order to determine the best assay conditions, variable concentrations of $\mathrm{MgCl}_{2}$ were included in the reaction mixture (data not shown).

Figure 2 shows the over-expression of MMLV (65 kDa) either in the soluble fraction (SN) or in the inclusion bodies (pellet), with a higher yield in the inclusion bodies (Figure 2a). From the soluble material the enzyme was purified by using His-tag affinity chromatography. However, a higher yield was obtained by purification starting from the inclusion bodies. While most of the authors purify the enzyme from the soluble material (Sun et al. 1998; Taube et al. 1998), we decided to pursue the purification from the inclusion bodies. In Figure $2 \mathrm{~b}$ it can be observed that $\mathrm{a}$ concentration of Triton X-100 $0 \%$ to $0.5 \%$ gives a better yield on the purification process than a $2 \%$ of Triton X-100.

Recombinant enzymes obtained in the lab were used to perform different amplification assays by using DNA from variable sources, such as animal (Figure 1c), vegetal or viral origin with excellent results (Pungitore et al. 2004).

Figure 3 shows an example where we analyzed the expression of two different genes by RT-PCR in a single assay (Multiplex PCR): simultaneous amplification was performed for the Ang II $\mathrm{AT}_{2}$ receptor (586 bp) and GAPDH (350 bp) genes, the second used as control. Both steps, the RT and the PCR were performed with the enzymes produced in the lab. These assays allow us to confirm that both enzymes are functional, since coamplification of the two target sequences was achieved. Different development stages were analyzed and a change in the expression level of $\mathrm{AT}_{2}$ receptor was observed with maximum expression at PND15, in agreement with previous results obtained by autoradiography (Arce et al. 2001) (Figure 3). 
The identity of the $\mathrm{AT}_{2}$ receptor fragment (586 bp) amplified from rat kidney DNA with our enzyme, was verified performing a restriction fragment length polymorphism (RFLP). Figure 4 shows the digestion products of the $586 \mathrm{bp}$ fragment with two different enzymes. Fragments of the expected size were obtained, thus indicating the correct identity of the amplified fragment of $\mathrm{AT}_{2}$ receptor.

When the goal is to express proteins as a reagent in biochemical or cell biology experiments, the authenticity of the protein function, such as high specific enzymatic activity is very important. The present results show that the enzymes obtained had their specific activity proved in different system and complex reactions such as the Multiplex RT-PCR.

Taq polymerase was a soluble protein, a fact that simplifies the purification protocol. Most of the published protocols include a purification step by precipitation with $\mathrm{NH}_{4} \mathrm{SO}_{4}$ (Engelke et al. 1990; Ottino, 1998). The novelty of the present purification protocol is that we took advantage of the resistance to high temperature of Taq polymerase. At $72^{\circ} \mathrm{C}$ most proteins were denatured and precipitated while Taq polymerase remained in solution. For the dialysis step we used $\beta$-mercaptoethanol instead of the recommended dTT, to protect the enzyme structure (Engelke et al. 1990; Ottino, 1998).

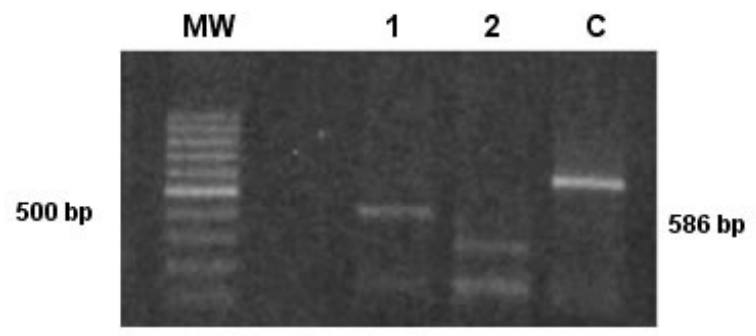

Figure 4. RFLP of the $A T_{2}$ amplified fragment. Lane $1: A T_{2}$ fragment digested with Pvull,. Lanel 2: digestion with Sspl. C: control product. MW molecular weight marker (100 bp ladder).

Different approaches were used to purify MMLV retrotranscriptase, however, in this paper the best results were obtained from the inclusion body fraction, while most of the authors use the soluble fraction. The level of accumulation and the chemical agent used to solubilize the inclusion bodies will be the major factors influencing the choice of refolding strategy. Since MMLV is a protein of a relatively small molecular weight $(65 \mathrm{kDa})$ we could recover the protein by slow dialysis which seems to be more appropriate than a rapid dilution of the denaturant. Another advantage of the inclusion bodies is that they can be stored at $-80^{\circ} \mathrm{C}$ and the enzyme recovered later.

In summary, we are reporting modified protocols for the expression and purification of both Taq polymerase and MMLV retrotranscriptase with a high yield and good specific activity as shown by different assays performed.

\section{ACKNOWLEDGMENTS}

M. Juri Ayub and S.E. Alvarez, have fellowships from CONICET (Consejo Nacional de Investigaciones Científicas y Técnicas, Arg). We thank to Dr. R. Masuelli for helpful suggestions. G.M. Ciuffo is a member of the CONICET researcher career.

\section{REFERENCES}

ARCE, M.E.; SANCHEZ, S.; SELTZER, A. and CIUFFO, G.M. Autoradiographic localization of angiotensin II receptors in developing rat cerebellum and brainstem. Regulatory Peptides, 2001, vol. 99, no. 1, p. 53-60.

AUSUBEL, Frederick M.; BRENT, Roger.; KINGSTON, Robert E.; MOORE, David D.; SEIDMAN, S.J.; SMITH John A. and STRUHL, Kevin. Short protocols in molecular biology. $4^{\text {th }}$ ed. Wiley, USA, 1999. 1104 p. ISBN 0-47132938-X.

BOLLAG, D.M.; ROZYCKI, M.D. and EDELSTEIN, S.J. Protein methods. Wiley-Liss USA. $2^{\text {nd }}$ ed. 1996. 432 p. ISBN 0-471-11837-0.

BOWDEN, G.A.; PAREDES, A.M. and GEORGIOU, G. Structure and morphology of protein inclusion bodies in $E$. coli. Bio/Technology, 1991, vol. 9, p. 725-730.

CHAFFOTTE, A.F.; GUILLOU, Y. and GOLDBERG, M.E. Inclusion bodies of the thermophillic endoglucanase D from Clostridium thermocellium are made of native enzyme that resist $8 \mathrm{M}$ urea. European Journal of Biochemistry, 1992, vol. 205, p. 369-373.

CIUFFO, G.M.; JOHREN, O., EGIDY, G.; HEEMSKERK, F.M.J. and SAAVEDRA, J.M. Heterogeneity of rat Ang II $\mathrm{AT}_{2}$ receptors. In: RAIZADA, M.; PHILLIP, I. and SUMMERS, C. eds. Recent Advances in Angiotensin Receptors. Plenum Press, 1996, p. 189-197.

DIEFFENBACH, C.W. and DVEKSLER, G.S. PCR Primer. A laboratory manual. Cold Spring Harbour: Laboratory Press, 1995. ISBN 0-87969-447-5.

ENGELKE, D.R.; KRISKOS, A.; BRUCK, M.E. and GINSBURG, D. Purification of Thermus aquaticus DNA polymerase expressed in Escherichia coli. Analytical Biochemistry, 1990, vol. 191, no. 2, p. 396-400.

LAWYER, F.C.; STOFFEL, S.; SAIKI, R.K.; MYAMBO, K.; DRUMMOND, R. and GELFAND, D.H. Isolation, characterization, and expression in Escherichia coli of the DNA polymerase gene from Thermus aquaticus. Journal of Biological Chemistry, 1989, vol. 264, no. 11, p. 6427-6437.

NICKENIG, G.; SACHINIDIS, A.; MICHAELSEN, F.; 
BOHM, M.; SEEWALD, S.; VETTER, H. Upregulation of vascular Angiotensin II receptor gene expression by lowdensity lipoprotein in vascular smooth muscle cells. Circulation, 1997, vol. 95, no. 2, p. 473-478.

OTTINO, P. Rapid purification of high activity Taq DNA polymerase expressed in transformed E. coli cells. Transactions of the Zimbabwe Scientific Association, 1998, vol. 72, p. 23-26.

PUNGITORE, C.R.; AYUB, M.J.; BORKOWSKI, E.J.; TONN C.E. and CIUFFO G.M. Inhibition of Taq DNA polymerase by catalpol. Cellular and Molecular Biology, 2004, vol. 50, no. 6, p. 767-772.

PRICE, N.C. and STEVENS, L. The purification of enzymes. In: Fundamentals of enzymology: The cell and molecular biology of catalytic proteins. Oxford University Press, 1999, p. 15-46.

PLUTHERO, F.G. Rapid purification of high-activity Taq DNA polymerase. Nucleic Acids Research, 1993, vol. 21, no. 20 , p. $4850-4851$.

SUN, D.; JESSEN, S.; LIU, C.; LIU, X; NAJMUDIN, S. and GEORGIADIS, M.M. Cloning, expression, and purification of a catalytic fragment of Moloney murine leukaemia virus reverse transcriptase: Crystallization of nucleic acid complexes. Protein Science, 1998, vol. 7, no. 7, p. 1575-1582.

TAUBE, R.; LOYA, S.; VIDAN, O.A.; PERACH, M. and HIZI, A. Reverse transcriptase of mouse mammary tumour virus: expression in bacteria, purification and biochemical characterization. Biochemical Journal, 1998, vol. 329, no. 3, p. 579-587.

THATCHER, D.R. and HITCHCOCK, A. Protein folding in biotechnology. In: PAIN, R.H. ed. Mechanism of Protein Folding. Oxford University Press, 1994. p. 229-261. 